\title{
IgG Avidity in Samples Collected on Filter Paper: Importance of The Early Diagnosis of Congenital Toxoplasmosis
}

\section{Avidez de IgG em amostras coletadas em papel filtro: Importância no diagnóstico precoce da toxoplasmose congênita}

\author{
Jéssica Yonara de Souza10 Taynara Cristina Gomes ${ }^{10}$ Hanstter Hallison Alves Rezende ${ }^{10}$ \\ Heloisa Ribeiro Storchilo ${ }^{10}$ Patrícia Giffron Rodrigues ${ }^{1}{ }^{\circledR}$ Ana Maria de Castro ${ }^{10}$
}

1 Universidade Federal de Goiás, Goiânia, GO, Brazil

Address for correspondence Jéssica Yonara de Souza, 235th Street,

Rev Bras Ginecol Obstet 2021;43(12):887-893. Setor Universitário, 74605-050, Goiânia, State of Goiás, Brazil (e-mail: jessica_yonara@hotmail.com).

\begin{abstract}
Keywords

- toxoplasmosis

- IgG avidity

- filter paper

- neonatal screening

- pregnancy

Objective The purpose of the present study is to standardize and evaluate the use of the immunoglobulin $\mathrm{G}(\mathrm{lgG})$ antibody avidity test on blood samples from newborns collected on filter paper to perform the heel test aiming at its implementation in ongoing programs.

Methods Blood samples from newborns were collected on filter paper simultaneously with the heel prick test. All samples were subjected to immunoglobulin M IgM and IgG enzyme-linked immunosorbent assays (ELISA). Peripheral blood was collected again in the traditional way and on filter paper from newborns with high IgG levels ( ${ }^{3} 3$ ). Three types of techniques were performed, the standard for measuring $\mathrm{lgG}$ in serum, adapted for filter paper and the technique of $\mathrm{IgG}$ avidity in serum and on filter paper. The results of the avidity test were classified according to the Rahbari protocol.

Results Among the 177 samples, 17 were collected in duplicate from the same child, 1 of peripheral blood and 1 on filter paper. In this analysis, 1 (5.88\%) of the 17 samples collected in duplicate also exhibited low IgG avidity, suggesting congenital infection. In addition, the results obtained from serum and filter paper were in agreement, that is, $16(94.12 \%)$ samples presented high avidity, with $100 \%$ agreement between the results obtained from serum and from filter paper.

Conclusion The results of the present study indicate that the avidity test may be another valuable method for the diagnosis of congenital toxoplasmosis in newborns.
\end{abstract}

received

November 22, 2020

accepted after revision

October 13, 2021
DOI https://doi.org/

10.1055/s-0041-1740272.

ISSN $0100-7203$. (c) 2021. Federação Brasileira de Ginecologia e Obstetrícia. All rights reserved.

This is an open access article published by Thieme under the terms of the Creative Commons Attribution License, permitting unrestricted use, distribution, and reproduction so long as the original work is properly cited. (https://creativecommons.org/licenses/by/4.0/)

Thieme Revinter Publicações Ltda., Rua do Matoso 170, Rio de Janeiro, RJ, CEP 20270-135, Brazil 


\section{Resumo}

\section{Palavras-chave \\ - toxoplasmose \\ - avidez de lgG \\ - papel filtro \\ - triagem neonatal \\ - gravidez}

Objetivo O objetivo do presente estudo é padronizar e avaliar a utilização do teste de avidez de anticorpos imunoglobulina G ( $\mathrm{gG}$ ) em amostras de sangue de recémnascidos (RNs) coletadas em papel filtro para a realização do teste do pezinho visando a implementação nos programas já vigentes.

Métodos Foram coletadas amostras de sangue de recém-nascidos em papel filtro simultaneamente ao teste do pezinho. Em todas as amostras, foram realizados os testes imunoenzimáticos (ELISA) imunoglobulina M (IgM) e IgG. Dos RNs que apresentaram altos índices de $\operatorname{lgG}\left({ }^{3} 3\right)$, foi novamente coletado sangue periférico da forma tradicional e em papel filtro. Foram realizadas técnicas padrão para a dosagem de $\mathrm{lgG}$ em soro, adaptadas para papel filtro, e a técnica de avidez de IgG em soro e em papel filtro. Os valores obtidos para o teste de avidez foram classificados de acordo com o protocolo de Rahbari.

Resultados Dentre as 177 recoletas, em 17 amostras foi realizada a coleta simultânea de sangue periférico e papel filtro da mesma criança. Nesta análise, 1 (5,88\%) das 17 amostras coletadas em duplicata obteve também baixa avidez de $\mathrm{gG}$, sugerindo infecção congênita da criança, e houve concordância entre os resultados obtidos em soro e em papel filtro: 16 (94,12\%) das amostras apresentaram alta avidez, com concordância de $100 \%$ entre os resultados obtidos em soro e em papel filtro.

Conclusão Os dados do presente trabalho evidenciam que o teste de avidez poderá ser mais um método valioso a ser utilizado no diagnóstico da toxoplasmose congênita em RNs.

\section{Introduction}

Congenital toxoplasmosis is an infectious disease caused by the transplacental transfer of Toxoplasma gondii tachyzoites from the primary infection of the mother, by reinfection, or by resurgence of a previous infection, and is particularly relevant because of the damage inflicted on the developing fetus. $^{1}$

Toxoplasmosis is one of the most harmful diseases for the fetus, particularly when the mother becomes infected in the $1^{\text {st }} 2$ trimesters of pregnancy. ${ }^{2}$ Studies in Brazil have revealed a prevalence of congenital toxoplasmosis of between 3 and 20 per 10,000 live births. ${ }^{3-6}$ Approximately $80 \%$ of vertically infected children show no symptoms at birth, but later exhibit signs of the disease, mainly with ocular, motor, and central nervous system involvement. ${ }^{7,8}$

The importance of diagnosing active infection by $T$. gondii during pregnancy and of confirming congenital transmission in newborns (NBs) cannot be overstated, because it allows for the adoption of measures of primary and secondary care, minimizing serious impairments caused by congenital transmission. ${ }^{9}$

In the routine laboratory tests offered by the Brazilian Unified Health System (SUS, in the Portuguese acronym), toxoplasmosis is diagnosed by means of serological tests based on the detection of specific antibodies of the classes of immunoglobulin $\mathrm{M}(\operatorname{IgM})$ and immunoglobulin $\mathrm{G}(\operatorname{IgG})$, mainly by means of the enzyme-linked immunosorbent assay (ELISA) method. ${ }^{10}$ However, assistance provided to pregnant women during prenatal care is still not satisfactory. Pregnant women often have access to exams only in the last month of pregnancy, when prenatal tests are performed in programs that use filter paper for serological screening. This situation is one of the main factors that limit the control and the prevention of infection, of confirmation of risk, and of congenital transmission. ${ }^{11}$

The diagnosis of toxoplasmosis is complex, and monitoring the NBs of mothers infected with T. gondii, confirming the infection, and providing early treatment, are crucial for the prognosis of the newborn. ${ }^{12}$ The literature recommends the IgG avidity test because it is a fast and inexpensive technique, and is an auxiliary method for optimization of the diagnosis of recent infection, and, therefore, of congenital toxoplasmosis. This recommendation favors the implementation of this technique in public health programs, especially in Brazil, where the incidence of congenital toxoplasmosis is high.

The infection is usually confirmed by laboratory tests that identify the parasite or by the presence of specific antibodies that do not cross the placental barrier (IgA, IgM or IgE) in the blood of the patient. ${ }^{13}$ Immunoglobulin $G$, which is a marker of chronic infection and crosses the transplacental barrier, is still not used as a marker of congenital infection. However, when IgG levels in NBs differ from maternal levels, they may suggest infection. ${ }^{14}$

The functional affinity of IgG antibodies for antigens is low in the primary antigen response and increases when the immune system reaches maturity. ${ }^{15}$ The IgG antibody avidity test analyzes the binding affinity of the antigen-antibody (AG-AB) complex. The AG-AB bond is easily dissociated in the acute phase of the disease because the synthesis of antibodies is recent. This is why IgG has low avidity for antigens, which are considered to be of low avidity $(<30 \%$, depending 
on what kits and protocols are used). On the other hand, AG$\mathrm{AB}$ complexes are difficult to dissociate in the chronic phase, exhibiting high IgG avidity, that is, late synthesis of antibodies considered to have high avidity. ${ }^{16}$

Therefore, the purpose of the present study was to standardize and assess the use of the IgG antibody avidity test on blood samples from NBs in order to optimize it and employ it in existing programs that use filter paper to collect blood for the neonatal heel prick test.

\section{Methods}

The present research project was submitted to the Brazilian online system for human subject research proposals, Plataforma Brasil, and was accepted under the Protocol No. 943,441 on February 11, 2015. Blood samples were collected between April 2016 and February 2017 at the maternity wards of the Hospital das Clínicas da Universidade Federal de Goiás (HC-UFG, in the Portuguese acronym) and of the Hospital e Maternidade Dona Iris (HDMI, in the Portuguese acronym), both in the municipality of Goiânia, state of Goiás, Brazil, and at the maternity ward of the Cais Nova Era (CNE, in the Portuguese acronym) in Aparecida de Goiânia, state of Goiás, Brazil. These maternity wards were chosen for convenience, and the patients came from the public health network of Goiânia, state of Goiás, Brazil.

The samples were collected on filter paper at the same time as the heel prick test was applied, upon the consent of the person responsible for the NB. The blood was collected from the lateral plantar region of the NB on Wathman Grade 1 filter paper, with the NB held in the burping position to ensure good blood circulation in the feet. After the circles marked on the filter paper were filled with blood, the papers were tagged and placed on horizontal shelves to dry for $\sim$ 3 hours at room temperature, between 15 and $20^{\circ} \mathrm{C}$, avoiding contact with other samples. The dry biological samples were then sent to the Laboratory for Parasite-Host Relationship Studies at the Universidade Federal de Goiás (LAERPH-UFG, in the Portuguese acronym).

All samples were subjected to IgM and IgG ELISA using Quibasa-Bioclin kits.

Newborns presenting higher IgG levels than the average level of patients tested in the LAERPH routine, that is, patients with a level $\geq 3$, served as a risk criterion for congenital infection. A new peripheral blood sample was collected from these infants, drawn in the traditional manner and on filter paper, within a period of up to 3 months after the $1^{\text {st }}$ blood sample collection, for confirmation and comparison of the serology on filter paper and for the $\operatorname{IgG}$ avidity test of the infant.

Avidity was evaluated using the protocol of Rahbari et al., ${ }^{17}$ with some adaptations for filter paper, as described in detail in Chart $\mathbf{1 .}$

Two plates, A and B, were used simultaneously to determine the reactivity. The serum samples were diluted 1:200 and $100 \mu$ were added per well. After incubation, plate A was washed 5 times with sample buffer from the Bioclin commercial kits (Quibasa Química Básica Ltda), while plate B was washed 3 times with sample buffer containing 6 Molar urea. The plates were then treated according to the instructions of the manufacturer. To validate the technique and standardize the use of 5-mm filter paper discs, tests were carried out

Chart 1 ELISA technique (immunoenzymatic assay) according to the protocol of the manufacturer of the Quibasa-Bioclin kit, a technique adapted for IgG avidity, and standardized in house with changes for the use of samples collected on filter paper

\begin{tabular}{|c|c|c|}
\hline $\begin{array}{l}\text { Standard technique to } \\
\text { measure serum IgG levels }\end{array}$ & $\begin{array}{l}\text { Technique adapted to measure IgG levels } \\
\text { on filter paper }\end{array}$ & $\begin{array}{l}\text { Technique to determine IgG avidity in } \\
\text { serum and on filter paper }\end{array}$ \\
\hline $100 \mu$ l of sample diluent $+5 \mu$ of sample & $\begin{array}{l}\text { Perforation with specific } 5 \mathrm{~mm} \text { diameter } \\
\text { perforator }+10 \mu \mathrm{l} \text { of sample diluent }\end{array}$ & $\begin{array}{l}\text { Serum: } 100 \mu \mathrm{l} \text { of sample diluent }+5 \mu \mathrm{l} \text { of } \\
\text { sample } \\
\text { Filter paper: } 100 \mu \mathrm{l} \text { of sample } \\
\text { diluent }+ \text { one } 5 \mathrm{~mm} \text { diameter filter paper } \\
\text { disc }\end{array}$ \\
\hline Incubation for 30 minutes at $37^{\circ} \mathrm{C}$ & Incubation for 30 minutes at $37^{\circ} \mathrm{C}$ & Incubation for 30 minutes at $37^{\circ} \mathrm{C}$ \\
\hline \multirow{8}{*}{$\begin{array}{l}\text { First wash with } 300 \mu \text { l of washing solution } \\
\text { previously prepared according to the } \\
\text { manufacturer's instructions }\end{array}$} & $\begin{array}{l}\text { Removal of filter papers and first wash with } \\
300 \mu \text { lof washing solution previously } \\
\text { prepared according to the manufacturer's } \\
\text { instructions }\end{array}$ & $\begin{array}{l}\text { First wash with } 300 \mu \text { l of previously } \\
\text { prepared solution of } 6 \mathrm{M} \text { Urea }\end{array}$ \\
\hline & Addition of $100 \mu$ l of conjugate & \\
\hline & Incubation for 30 minutes at $37^{\circ} \mathrm{C}$ & \\
\hline & $\begin{array}{l}\text { Second wash with } 300 \mu \text { of washing solution } \\
\text { prepared according to the manufacturer's ins }\end{array}$ & $\begin{array}{l}\text { previously } \\
\text { structions }\end{array}$ \\
\hline & Addition of $50 \mu$ l of substrate $A$ and $50 \mu$ of & substrate B \\
\hline & Incubation for 10 minutes at $37^{\circ} \mathrm{C}$ & \\
\hline & Addition of $50 \mu$ of stop solution & \\
\hline & Reading on filters at $450 \mathrm{~nm}$ and $630 \mathrm{~nm}$ & \\
\hline
\end{tabular}

Abbreviations: IgG, Immunoglobulin G.

Source: Rahbari et al. ${ }^{17}$ 
Table 1 Comparison of Immunoglobulin G anti-Toxoplasma gondii, obtained by the ELISA test on serum samples from children and their respective mothers collected 3 months after birth

\begin{tabular}{|c|c|c|c|c|}
\hline Results & Mother & & Child & \\
\hline & Absolute number & $\%$ & Absolute number & $\%$ \\
\hline Reagent (lgM) & 0 & 0 & 0 & 0 \\
\hline Reagent (lgG) & 167 & 94.36 & 167 & 94.36 \\
\hline Reactive mother and non-reactive child (IgG) & 5 & 2.82 & 5 & 2.82 \\
\hline Non-reactive mother and child (IgG) & 5 & 2,82 & 5 & 2,82 \\
\hline Total samples & 177 & 100 & 177 & 100 \\
\hline
\end{tabular}

Abbreviations: IgG, immunoglobulin G; IgM, immunoglobulin M.

concomitantly using the samples collected on filter paper using the Virion Serion commercial kit for filter paper and the Quibasa-Bioclin commercial kits used in our study. After the readings and technical validations, the cutoff of each plate and the indices of each sample were calculated to determine $\operatorname{Ig} G$ and IgM. The percentage of $\operatorname{Ig} G$ avidity was calculated based on the following formula: $\mathrm{AI}=\mathrm{Abs}(\mathrm{U}+) /$ Abs (U-) x 100, ${ }^{1}$ where the result of absorbance of wells washed with PBS-urea $(U+)$ was divided by the absorbances of wells washed with PBS (U-) and then multiplied by $100 .{ }^{17}$ The values obtained in the avidity test were classified according to the protocol proposed by Rahbari et al., ${ }^{17}$ and patients with avidity values $\leq 30 \%$ were considered as having low IgG avidity.

\section{Results}

A total of 1,277 whole blood samples were collected on filter paper from 3- to 7-day-old NBs in the maternity wards of the HC-UFG, the HMDI, and the CNE. The ELISA test detected the presence of anti-T. gondii IgG antibodies in 44.4\% (567/1,277) of the analyzed samples. Of the 567 blood samples collected on filter paper that were reactive to IgG, 57.67\% (327/567) presented an absorbance value $\geq 3.0$ and were considered at risk in the present study. Following the proposed methodology, the mothers of infants whose blood samples on filter paper showed ELISA titers $\geq 3$ were contacted and peripheral blood samples were collected from their babies before they were 3 months old (-Table $\mathbf{1}$ ).

1. Comparison of the results of blood on filter paper and peripheral blood

A total of 177 pairs of samples were collected, and the results of 167 (94.36\%) peripheral blood samples from NBs were in agreement with those obtained in the heel prick test on filter paper. However, 10 (5.64\%) peripheral blood samples showed results that were inconsistent with those obtained on filter paper.

2. Comparison of serology in samples collected simultaneously of peripheral blood of infants and their mothers

All the 177 pairs of recollections (mothers and children) performed showed negative results for IgM. Regarding IgG, 167 pairs $(94,36 \%)$ of samples from both mother and child were detected with the presence of anti-T gondii IgG antibodies.

3. High IgG avidity - filter paper versus peripheral blood

The 167 samples from babies that remained IgG-positive after 3 months were subjected to the $\operatorname{IgG}$ avidity test to determine the binding strength of this immunoglobulin with the epitope, in order to ascertain if the infection was a recent or past infection of the mother. Among these 167 samples, $163(97.60 \%)$ showed high avidity of antibodies, and $4(2.40 \%)$ of the samples showed low avidity of IgG antibodies, which is indicative of a recent infection. Congenital infection was then confirmed in $50 \%$ of the samples from infants with low IgG antibody avidity by the Western Blot method. For infants with high IgG avidity, the finding must be confirmed by other methods. Among the 167 samples collected in duplicate, 17 samples were randomly collected from peripheral blood and filter paper simultaneously from the same infant. In this analysis, 1 (5.88\%) of the 17 samples collected in duplicate also showed low IgG avidity, suggesting congenital infection of the infant, and the results obtained in serum and in filter paper were in agreement. Sixteen (94.12\%) of the samples showed high avidity, with $100 \%$ agreement between the results obtained in serum and in filter paper, as shown in -Table 2. ${ }^{17}$

\section{Discussion}

The clinical diagnosis of toxoplasmosis is complex, and sometimes inaccurate, as most pregnant women are asymptomatic. Moreover, when they do present symptoms, these may be mistaken for other infectious agents, such as Cytomegalovirus, Herpes simplex virus (HSV-1 or HSV-2), Rubella virus, HIV, Epstein Barr, Treponema pallidum, Listeria monocytogenes, Borrelia burgdorferi (Lyme disease), and Trypanosoma cruzi (Chagas disease). ${ }^{18}$

According to data presented by the Association of Parents and Friends of Disabled Children (APAE, in the Portuguese acronym) in Goiânia, state of Goiás, Brazil, from 2003 to 2013, 9,247,974 prenatal screening tests were performed on mothers in their $1^{\text {st }}$ trimester of pregnancy, but only 653,562 pregnant women underwent prenatal tests in the $3^{\text {rd }}$ trimester. In other words, $\sim 93 \%$ of mothers did not undergo the recommended toxoplasmosis screening test during 
Table 2 Comparison of anti-Toxoplasma gondii IgG avidity values obtained by ELISA using Quibasa-Bioclin kits adapted for IgG avidity in serum samples and adapted in house for samples in filter paper, collected simultaneously 3 months after birth

\begin{tabular}{lllll}
\hline Samples & $\begin{array}{l}\text { IgG avidity } \\
\text { serum }\end{array}$ & $\begin{array}{l}\text { IgG avidity } \\
\text { filter paper }\end{array}$ & $\begin{array}{l}\text { IgG serum } \\
\text { (ELISA } \\
\text { index) }\end{array}$ & $\begin{array}{l}\text { IgG filter } \\
\text { paper } \\
\text { (ELISA } \\
\text { index) }\end{array}$ \\
\hline Patient 1 & $26 \%$ & $26 \%$ & 3.52 & 3.31 \\
Patient2 & $52 \%$ & $56 \%$ & 2.94 & 2.75 \\
Patient3 & $48 \%$ & $43 \%$ & 2.65 & 2.37 \\
Patient4 & $89 \%$ & $89 \%$ & 2.04 & 1.47 \\
Patient5 & $61 \%$ & $87 \%$ & 1.51 & 1.71 \\
Patient6 & $56 \%$ & $73 \%$ & 2.0 & 2.02 \\
Patient7 & $87 \%$ & $86 \%$ & 1.27 & 0.99 \\
Patient8 & $95 \%$ & $77 \%$ & 16.70 & 17.21 \\
Patient9 & $76 \%$ & $84 \%$ & 1.24 & 1.56 \\
Patient10 & $77 \%$ & $88 \%$ & 3.72 & 2.59 \\
Patient11 & $81 \%$ & $91 \%$ & 5.13 & 4.60 \\
Patient12 & $86 \%$ & $73 \%$ & 3.44 & 4.53 \\
Patient13 & $52 \%$ & $55 \%$ & 3.86 & 3.54 \\
Patient14 & $72 \%$ & $81 \%$ & 2.25 & 2.18 \\
Patient15 & $94 \%$ & $92 \%$ & 1.88 & 1.83 \\
Patient16 & $53 \%$ & $99 \%$ & 4.72 & 2.17 \\
Patient17 & $52 \%$ & $55 \%$ & 3.86 & 3.54 \\
\hline
\end{tabular}

Abbreviations: ELISA, enzyme-linked immunosorbent assay; IgG, Immunoglobulin G.

Source: Rahbari et al. ${ }^{17}$

pregnancy, although this is the third most frequent disease diagnosed among the 24 tests performed during prenatal care on a total of 27,924 pregnant women with confirmed infections, while hepatitis B and syphilis rank in first and second place, respectively. ${ }^{19}$

Neonatal infection is usually asymptomatic, and when identified, may present clinical signs similar to erythroblastosis fetalis and to certain degenerative diseases. The clinical examination only suggests the possibility of this etiology, even when toxoplasmosis is symptomatic. ${ }^{20}$

Most studies, including those by Buffolano et al. ${ }^{21}$ and Cañedo-Solares et al., ${ }^{22}$ focus on the predictive value of the IgG avidity test in pregnant women, demonstrating the importance of this test in the diagnosis during the acute phase of the infection, with $100 \%$ sensitivity and $92.7 \%$ specificity. ${ }^{23,24}$ However, few studies in the literature focused on the use of avidity in the blood of NBs, and observed low IgG avidity values in infected NBs. ${ }^{25}$

The focus of the present study was to measure and analyze the levels of $\operatorname{IgG}$ and test the $\operatorname{Ig} G$ avidity in peripheral blood from NBs, following the aforementioned criteria. However, based on our findings and on the promising potential of this method in the early diagnosis of congenital toxoplasmosis, the possibility of validating an IgG avidity technique on filter paper would be highly relevant, given its remarkable contribution to the primary care system for NBs, such as in the heel prick test, for example.

Brazil's National Neonatal Screening Program (PNTN, in the Portuguese acronym), known as the "Heel Prick Test", was created and implemented by the Ministry of Health under Directive MG/MS No. $822 / 01,{ }^{26}$ and is aimed at the early detection of disorders and diseases in NBs to ensure the appropriate intervention and potentiation of treatment. Almost 3 million children are born each year in Brazil, and the coverage of NB screening varies according to the state. Nevertheless, in 2017 (the most recent data), the national coverage of the heel prick test reached $85.8 \%$, demonstrating the strong support of this program by the population. ${ }^{27}$

The clearly greater adherence to the heel prick test than to prenatal testing of the mother underscores the bias against the prenatal program. Hence, to compensate for this lack, the IgG avidity test on filter paper can be of great value as part of the methodological approaches carried out in the heel prick test.

Detection of low-avidity $\operatorname{IgG}$ as early as in the heel prick test of NBs may streamline the diagnosis of congenital infection. According to Fonseca et al., ${ }^{23}$ NBs exposed to $T$. gondii show elevated serum IgM and IgG levels, and when their IgG shows low avidity, they exhibit more severe symptoms of congenital toxoplasmosis. The aforementioned authors observed that high IgG avidity in NBs probably indicates a lower risk of infection by $T$. gondii. ${ }^{28}$

The 10 discordant samples reported in item 1 of the Results section can be explained by the 61.1 to $99.3 \%$ sensitivity rate of the ELISA test and by the timeframe of the $2^{\text {nd }}$ blood collection, which, in some cases, was 3 months. Despite this slight divergence, the use of serology on samples collected on filter paper has already been standardized and is widely used, and the technique is considered highly efficient and reproducible. ${ }^{29-32}$

As for the 4 samples that presented low IgG antibody avidity described under item 2 of the Results section, and considering that IgG crosses the placental barrier, this antibody may have been passed on to the fetus during pregnancy. However, this does not diminish its relevance, since it may indicate primary maternal infection, with a considerable risk of vertical transmission. This situation may indicate a recent infection or even a current production of low avidity IgG by the NB, which in both cases is extremely important for the diagnosis and earliest possible treatment. ${ }^{33,34}$

The fact that not all samples with high IgG concentrations were collected in duplicate was due to the difficulty in communicating with the parents of the infants and to their lack of interest in allowing a second blood collection, as the infants were apparently asymptomatic. It should be noted that the lack of communication is one of the major problems in the diagnosis of congenital toxoplasmosis, as NBs are often born asymptomatic and only present sequelae months or even years after their birth. ${ }^{30,35-37}$

Our data reveal that screening infants with high IgG titers, allied to avidity testing, can contribute to the tracking and early diagnosis of postnatal toxoplasmosis. 


\section{Conclusion}

The IgG avidity test proved to be efficient because it enabled the detection of patients with low avidity in $2.4 \%$ of the analyzed samples, contributing to the early identification of congenital toxoplasmosis in $50 \%$ of these samples, subsequently confirmed by Western Blot tests. Screening for toxoplasmosis in NBs with high IgG titers, allied with avidity testing, can be performed on filter paper and easily included in the current heel prick test. Thus, it can contribute to tracking and early diagnosis, since congenital toxoplasmosis is difficult to diagnose and depends on several factors, particularly on those pertaining to the age of the fetus when infection set in, and on the absence of symptoms in infected infants, which makes their identification even more difficult. The data reported here indicate that the avidity test may be another valuable method for the diagnosis of congenital toxoplasmosis in NBs. This method is inexpensive and easy to implement on blood samples that present high concentrations of $\operatorname{IgG}$ detected in the heel prick test, the basic test of the postnatal program, offered nationwide by the SUS.

\section{Contributions}

All authors participated in the concept and design of the study, analysis and interpretation of data, in the draft or revision of the manuscript, and they have approved the manuscript as submitted. All authors are responsible for the reported research.

\section{Conflict of Interests}

The authors have no conflict of interests to declare.

\section{Acknowledgements}

We would like to thank the management and the staff of the Hospital Maternidade Dona Íris (HMDI, in the Portuguese acronym), the Hospital das Clínicas da Universidade Federal de Goiás (HC-UFG, in the Portuguese acronym), and the Nova Era Center for Comprehensive Health Care (CNE/CAIS, in the Portuguese acronym) for the partnership developed throughout the present study. We also thank all the patients who participated in the present study and the financial support, public call $\mathrm{N}^{\circ} 12 / 2013$ Programa Pesquisa para o SUS: Gestão Compartilhada em Saúde - PPSUS/GO - FAPEG.

\section{References}

1 Teimouri A, Mohtasebi S, Kazemirad E, Keshavarz H. Role of Toxoplasma gondii IgG avidity testing in discriminating between acute and chronic toxoplasmosis in pregnancy. J Clin Microbiol. 2020;58(09):e00505-e00520. Doi: 10.1128/JCM.00505-20

2 Cruz AM, Araújo AM, Fit SS, Vieira LC, Felix LC, Sousa DS, et al. Incidência e delineamento epidemiológico de gestantes com toxoplasmose, em uma unidade de referência de SantarémPará. Livro de Resumos da Feira de Trabalhos Acadêmicos e Científicos-Fetac; Nov 2014; Santarém, PA.

3 Bahia-Oliveira LM, Jones JL, Azevedo-Silva J, Alves CC, Oréfice F, Addiss DG. Highly endemic, waterborne toxoplasmosis in north
Rio de Janeiro state, Brazil. Emerg Infect Dis. 2003;9(01):55-62. Doi: 10.3201/eid0901.020160

4 Neto EC, Anele E, Rubim R, Brites A, Schulte J, Becker D, et al. High prevalence of congenital toxoplasmosis in Brazil estimated in a 3year prospective neonatal screening study. Int J Epidemiol. 2000; 29(05):941-947. Doi: 10.1093/ije/29.5.941

5 Lago EG, Carvalho RL, Silva VB, Fiori RM. Screening for Toxoplasma gondii antibodies in 2,513 consecutive parturient women and evaluation of newborn infants at risk for congenital toxoplasmosis. Sci Med (Porto Alegre). 2009;19(01):27-34. oai:doaj.org/ article:ca7185a278114cd1925d5ba6f2301bef

6 Carvalheiro CG, Mussi-Pinhata MM, Yamamoto AY, De Souza CB, Maciel LM. Incidence of congenital toxoplasmosis estimated by neonatal screening: relevance of diagnostic confirmation in asymptomatic newborn infants. Epidemiol Infect. 2005;133 (03):485-491. Doi: 10.1017/s095026880400353x

7 Wilson CB, Remington JS, Stagno S, Reynolds DW. Development of adverse sequelae in children born with subclinical congenital Toxoplasma infection. Pediatrics. 1980;66(05):767-774

8 Soares JAS, Caldeira AP. Congenital toxoplasmosis: the challenge of early diagnosis of a complex and neglected disease. Rev Soc Bras Med Trop. 2019;52:e20180228. Doi: 10.1590/0037-86820228-2018

9 Amendoeira MR, Millar PR. Congenital toxoplasmosis: the importance of implementing clinical practice guidelines. The Lancet Regional Health - Americas. 2021;23:15-24. https://doi.org/10. 1016/j.lana.2021.100023

10 Reis MM, Tessaro MM, d 'Azevedo PA. Perfil sorológico para toxoplasmose em gestantes de um hospital público de Porto Alegre. Revista Brasileira de Ginecologia e Obstetrícia. 2006;28 (03):. Doi: 10.1590/s0100-72032006000300004

11 Gomes Filho C, Macedo Filho JV, Minuzzi AL, Gomes MM, Luquetti AO. Detecção de doenças transmissíveis em gestantes no estado de Goiás: o teste da mamãe. Revista de Patologia Tropical/Journal of Tropical Pathology. 2016;45(04):369-386. https://doi.org/10. 5216/rpt.v45i4.44610

12 Garnaud C, Fricker-Hidalgo H, Evengård B, Álvarez-Martínez MJ, Petersen E, Kortbeek LM, et al; under the auspices of the ESGCP of ESCMID. Toxoplasma gondii-specific IgG avidity testing in pregnant women. Clin Microbiol Infect. 2020;26(09):1155-1160. Doi: 10.1016/j.cmi.2020.04.014

13 Kheirandish F, Ezatpour B, Fallahi SH, Tarahi MJ, Hosseini P, Rouzbahani AK, et al. Toxoplasma serology status and risk of miscarriage, a case-control study among women with a history of spontaneous abortion. Int J Fertil Steril. 2019;13(03):184-189. Doi: $10.22074 /$ ijfs.2019.5740

14 Figueiró-Filho EA, Senefonte FR, Lopes AH, Morais OO, Souza Júnior VG, Maia TL, et al. [Frequency of HIV-1, rubella, syphilis, toxoplasmosis, cytomegalovirus, simple herpes virus, hepatitis B, hepatitis C, Chagas disease and HTLV I/II infection in pregnant women of State of Mato Grosso do Sul]. Rev Soc Bras Med Trop. 2007;40(02): 181-187. Doi: 10.1590/S0037-86822007000200007Portuguese.

15 Koppe JG, Loewer-Sieger DH, de Roever-Bonnet H. Results of 20year follow-up of congenital toxoplasmosis. Lancet. 1986;1 (8475):254-256. Doi: 10.1016/S0140-6736(86)90785-3

16 Montoya JG, Liesenfeld O. Toxoplasmosis. Lancet. 2004;363 (9425):1965-1976. Doi: 10.1016/S0140-6736(04)16412-X

17 Rahbari AH, Keshavarz H, Shojaee S, Mohebali M, Rezaeian M. IgG avidity ELISA test for diagnosis of acute toxoplasmosis in humans. Korean J Parasitol. 2012;50(02):99-102. Doi: 10.3347/kjp. 2012.50.2.99

18 Diniz EM. O diagnóstico da toxoplasmose na gestante e no recémnascido [dissertation]. São Paulo: Faculdade de Medicina, Departamento de Pediatria, Universidade de São Paulo. 2006; 28:222-222

19 Storchilo HR. Triagem pelo teste do pezinho para diagnóstico precoce da infecção congênita para toxoplasmose em três 
unidades de saúde pública da região metropolitana de Goiânia, Goiás [dissertação]. Goiânia: Universidade Federal de Goiás; 2016

20 Rey L. Parasitologia: parasitos e doenças parasitárias do homem nas Américas e na África. 2a ed. Rio de Janeiro: Guanabara Koogan; 1991

21 Buffolano W, Lappalainen M, Hedman L, Ciccimarra F, Del Pezzo $\mathrm{M}$, Rescaldani R, et al. Delayed maturation of IgG avidity in congenital toxoplasmosis. Eur J Clin Microbiol Infect Dis. 2004; 23(11):825-830. Doi: 10.1007/s10096-004-1226-1

22 Cañedo-Solares I, Ortiz-Alegría LB, Figueroa-Damián R, BustosBahena ML, González-Henkel H, Calderón-Segura E, et al. Toxoplasmosis in pregnancy: determination of IgM, IgG and avidity in filter paper-embedded blood. J Perinatol. 2009;29(10):668-672. Doi: $10.1038 /$ jp.2009.79

23 Fonseca ZC, Rodrigues IM, Melo NC, Avelar JB, Castro AM, Avelino MM. IgG avidity test in congenital toxoplasmosis diagnoses in newborns pathogens. 2017;6(02):26. Doi: 10.3390/pathogens6020026

24 Candolfi E, Pastor R, Huber R, Filisetti D, Villard O. IgG avidity assay firms up the diagnosis of acute toxoplasmosis on the first serum sample in immunocompetent pregnant women. Diagn Microbiol Infect Dis. 2007;58(01):83-88. Doi: 10.1016/j.diagmicrobio.2006.12.010

25 Fonseca FC, Rodrigues IM, Melo NC, Castro AN, Avelino MM. Importância do teste de avidez de IgG na toxoplasmose congênita. Revista de Patologia Tropical/Journal of Tropical Pathology. 2016; 45(01):42-54. Doi: 10.5216/rpt.v45i1.40078

26 Ministério da Saúde. Portaria No. 822, de 6 de junho de 2001. Institui, no âmbito do Sistema Único de Saúde, o Programa Nacional de Triagem Neonatal / PNTN [Internet]. 2001 [cited 2020 Aug 12]. Available from: https://bvsms.saude.gov.br/bvs/ saudelegis/gm/2001/prt0822_06_06_2001.html

27 Ministério da Saúde. Programa Nacional da Triagem Neonatal. Cobertura do Programa Nacional de Triagem Neonatal [Internet]. Brasília (DF): Ministério da Saúde; 2018 [cited 2020 Aug 12]. Available from: https://antigo.saude.gov.br/acoes-e-programas/ programa-nacional-da-triagem-neonatal/indicadores-da-triagemneonatal-no-brasil

28 Webster JP. Review of "Toxoplasmosis of animals and humans (Second Edition)" by J.P. Dubey Parasit Vectors. 2010;3(01):1-2. Doi: $10.1186 / 1756-3305-3-112$
29 Dunn D, Wallon M, Peyron F, Petersen E, Peckham C, Gilbert R. Mother-to-child transmission of toxoplasmosis: risk estimates for clinical counselling. Lancet. 1999;353(9167):1829-1833. Doi: 10.1016/S0140-6736(98)08220-8

30 Naessens A, Jenum PA, Pollak A, Decoster A, Lappalainen M, Villena I, et al. Diagnosis of congenital toxoplasmosis in the neonatal period: A multicenter evaluation. J Pediatr. 1999;135 (06):714-719. Doi: 10.1016/S0022-3476(99)70090-9

31 Zhang K, Wang L, Lin G, Sun Y, Zhang R, Xie J, et al. Results of the national external quality assessment for toxoplasmosis serological testing in China. PLoS One. 2015;10(06):e0130003. Doi: 10.1371/journal.pone.0130003

32 Sartori AL, Minamisava R, Avelino MM, Martins CA. [Prenatal screening for toxoplasmosis and factors associated with seropositivity of pregnant women in Goiânia, Goiás]. Rev Bras Ginecol Obstet. 2011;33(02):93-98. Doi: 10.1590/S0100-72032011 000200007

33 Avelar JB, Rezende HH, Storchilo HR, Candido RR, Amaral WN, Avelino MM, Avelino MM, et al. Reativação da toxoplasmose durante o oitavo mês de gestação. Revista Norte Mineira de Enfermagem. 2015;4(01):57-69

34 Avelar JBToxoplasmose crônica em gestantes. Avaliação da prevalência, fatores de risco e acompanhamento de um grupo de recém-nascidos em Goiânia - Goiás [tese]. Goiânia: Universidade Federal de Goiás; 2013

35 Pena LT, Discacciati MG. Importância do teste de avidez da imunoglobulina $\mathrm{G}(\operatorname{Ig} G)$ antiToxoplasma gondii no diagnóstico da toxoplasmose em gestantes. Universidade de São Paulo: Revista do Instituto Adolfo Lutz. 2013;72(02):117-123. Doi: 10.18241/0073-98552013721551

36 Deshpande PS, Kotresha D, Noordin R, Yunus MH, Saadatnia G, Golkar M, et al. IgG avidity Western blot using Toxoplasma gondii rGRA-7 cloned from nucleotides 39-711 for serodiagnosis of acute toxoplasmosis. Rev Inst Med Trop São Paulo. 2013;55(02):79-83. Doi: 10.1590/S0036-46652013000200003

37 Garcia MG, Ferreira EA, Oliveira FP. Análise da compreensão de pais acerca do teste do pezinho. São Paulo: Journal of Human Growth and Development. 2007;17(01):1-12 